\title{
Correlations between electromyographic amplitude of the erector spinae and the location, direction and number of spinal curvatures in young school children
}

\section{Korelacje między elektromiograficzna amplituda prostownika grzbietu a lokalizacja, kierunkiem i liczbą łuków skrzywienia kręgosłupa u dzieci w młodszym wieku szkolnym}

Jacek Wilczyński, Przemysław Karolak

Institute of Health Sciences, Collegium Medicum, Jan Kochanowski University, Kielce, Poland

Key words: scoliosis, scoliotic posture, optoelectronic method, electromyographic amplitude.

Słowa kluczowe: skolioza, postawa skoliotyczna, metoda optoelektroniczna, elektromiograficzna amplituda.

\begin{abstract}
Introduction: The location, direction and number of spinal curvatures are typical features characterising scoliosis. Electromyographic testing of the erector spinae is used to observe the development of scoliosis.

Aim of the research: To analyse the relationship between the features of scoliosis in the form of location, direction and number of spinal curvatures and surface electromyography amplitude of the erector spinae in young school children.

Material and methods: The study included 103 (41\%) children with scoliosis, 141 (56.17\%) children with scoliotic posture and 7 (3.0\%) children with correct posture. Body posture and the spine were assessed using the surface topography method. Electromyographic amplitude of the erector spinae was examined with the Noraxon TeleMyo DTS apparatus.

Results and conclusions: In the group of children with scoliosis, the most common was curvature in the thoracic segment. Girls experienced left-sided curvature slightly more often, the same in the scoliosis group, and in boys, right-sided curvature prevailed. Single-curvatures were the most common. The greatest generalised amplitude of the erector spinae SEMG occurred in scoliosis in both girls and boys. A significant relationship between the location, direction and number of spinal curvatures and SEMG amplitude of the erector spinae has been demonstrated. The increase in erector spinae activity correlates with the progression of scoliosis.
\end{abstract}

\begin{abstract}
Streszczenie
Wprowadzenie: Lokalizacja, kierunek i liczba łuków skrzywienia kręgosłupa to typowe cechy charakteryzujące skoliozę. Choroba ta, z wieloma nierozwiązanymi zagadnieniami dotyczącymi etiopatogenezy oraz metod leczenia zachowawczego, należy do stale aktualnych problemów wymagających nowych poszukiwań oraz intensywnych badań. Zaburzenie aktywności i napięcia prostownika grzbietu przyczynia się do rozwoju skrzywienia i wiele świadczy o tym, że zmiany te są pierwotną przyczyną skoliozy idiopatycznej. Badania elektromiograficzne prostownika grzbietu służą do obserwacji rozwoju skoliozy.

Cel pracy: Analiza związku między lokalizacją, kierunkiem i liczbą łuków skrzywienia kręgosłupa a elektromiograficzną amplitudą prostownika grzbietu u dzieci we wczesnym wieku szkolnym.

Materiał i metody: Analizie poddano 103 (41\%) dzieci ze skoliozą, 141 (56,17\%) dzieci z postawą skoliotyczną i 7 (3,0\%) dzieci z poprawną postawą. Postawę ciała i kręgosłup oceniono metodą fotogrametrii przestrzennej. Amplitudę elektromiograficzną prostownika grzbietu zbadano aparatem Noraxon TeleMyo DTS.

Wyniki i wnioski: W grupie dzieci ze skoliozą najczęściej występowało skrzywienie o lokalizacji piersiowej. U dziewcząt nieznacznie częściej pojawiał się lewostronny kierunek skrzywienia, również w grupie skolioz, natomiast u chłopców prawostronny kierunek skrzywienia. Najczęściej stwierdzano skrzywienia jednołukowe. Największa uogólniona amplituda SEMG prostownika grzbietu wystąpiła w skoliozach zarówno u dziewcząt, jak i chłopców. Wykazano istotny związek między lokalizacją, kierunkiem i liczbą łuków skrzywienia kręgosłupa a amplitudą SEMG prostownika grzbietu. Wzrost aktywności prostownika grzbietu koreluje z postępem skoliozy.
\end{abstract}




\section{Introduction}

The location, direction and number of spinal curvatures are typical features characterising scoliosis $[1,2]$. This disease, with many unsolved problems regarding etiopathogenesis and conservative treatment methods, is a constantly current issue requiring new and intensive research [3]. Among spinal curvatures, we distinguish those that do not show any tendency towards aggravation, and a certain type of malignant course, poorly susceptible to existing methods of conservative treatment $[4,5]$. The main task in the therapy of this disease should be to identify cases that are prone to progression as early as possible and to prevent their progression using conservative methods [6].

Treatment of scoliosis is made difficult by not knowing the causes of this disease. The most numerous group comprises idiopathic scoliosis of unknown aetiology (about 90\%) [7]. The formation and development of scoliosis depend on two basic factors: aetiological and biomechanical. The first can be very diverse; it initiates the formation of a curvature. The second is common to all curvatures, regardless of their aetiology; it works according to the laws of gravity and the laws of growth. This factor controls the development of scoliosis. The effect of gravity along the long axis of the spine is important here. Under normal conditions, the spine retains its vertical form with physiological anteroposterior bends thanks to so-called internal balance. This balance consists of both passive and active elements. Correctly shaped vertebrae connected by joints and ligaments are subjected to compressive forces of gravity [8]. Intervertebral discs, thanks to their elasticity and tension, counteract the compressive force and distribute the loads evenly over the entire surfaces of the vertebrae. Due to this coordinated action, the spine and trunk muscles ensure active, balanced positioning of the spine in a vertical position.

In the approach to the pathogenesis and pathomechanics of scoliosis, there are two opposing groups of views. Some researchers see scoliosis nuclei in the vertebrae, intervertebral discs or ligaments, i.e. in the passive support apparatus of the spine. They point to the basic importance of disorders in the epiphyseal plates of the vertebrae, as well as in the ribs and ligaments of the spine in the formation and development of scoliosis [9]. Clinically, in the course of scoliosis formation, disorders in the epiphyseal plates were also noted, and the encouraging results of scoliosis treatment by destroying the growth cartilage on the convex side of the curvature confirmed the special role of disorders in these cartilages in the pathogenesis of idiopathic scoliosis. However, currently, most researchers consider disorders of muscular balance to be primary, while changes in the passive elements of the spine are secondary [10]. Muscle balance of one of the main active stabilisers of the spine, i.e. the erector spinae, may be disturbed due to discrete changes in the central nervous system [11].
The disturbance of activity and tension of the erector spinae contributes to the development of the curvature and much testifies to the fact that these changes are the primary cause of idiopathic scoliosis [12].

Regardless of the approach to pathogenesis, it remains an undoubted fact that under the influence of the aetiological factor, the internal balance of the spine is disturbed [13]. Lateral curvature is formed in one part of the spine, which we call the primary curvature. In the first phase, only narrowing of the intervertebral discs on the concave side of the curvature and loss of elasticity are found [4]. At the same time, an increase in the amplitude of the erector spinae in electromyographic examination is observed [14].

Electromyographic testing of the erector spinae is used to observe the development of scoliosis. It is also used in studies on its aetiology and progression. Attention is drawn to the asymmetry of the EMG amplitude of the erector spinae between the concave and convex sides of the curvature and at various levels of the spine. Electromyographic examination is a method of receiving and analysing myoelectric signals formed as a result of selective penetration of sodium and potassium ions in cell membranes of muscle fibres [14]. The electromyographic signal can be recorded from the muscle using inserted needle electrodes (EMG) or surface electrodes (SEMG). The surface electromyography amplitude reflects muscle activity and tension. It is expressed in microvolts $(\mu \mathrm{V})$. Its value covers the range from a few $\mu \mathrm{V}$ at rest to several dozen $\mathrm{mV}$ at the time of maximal muscle tension [15]. By examining the signal amplitude, periods of greater or lesser muscle activity can be indicated.

\section{Aim of the research}

The aim of the study was to analyse the relationship between the features of scoliosis in the form of location, direction and number of spinal curvature and the amplitude of erector spinae surface electromyography in young school children.

\section{Material and methods}

Research was carried out at the Posturology Laboratory. The study included 113 (45.02\%) girls and 138 (54.98\%) boys, totalling 251 subjects. The selection was deliberate and random. Before beginning the study, the following documents were analysed: information on the subject containing detailed data on the purpose and rules of conducting the study, consent form of the parent/legal guardian for the child's participation, declaration of the parent/legal guardian of the child for the processing of data related to participation in the study, declaration, signed with first name and surname, in which informed consent for the examination was obtained from all parents/legal guardians of children. Each person could refuse to 
participate in the research or withdraw at any time, including during the study, without suffering any consequences. The inclusion criteria were: age $7-8$ years, no certificate of physical or intellectual disability, no diagnosed syndromes or congenital defects of the central nervous system (CNS) or locomotor system, preventing proper psychomotor development, no genetic syndromes, hormonal disorders, neuromuscular diseases, no congenital motor system defects, written consent of parents or guardians for testing. The exclusion criteria were: the presence of syndromes and congenital defects of the CNS or the musculoskeletal system, preventing proper psychomotor development, a certificate of physical or intellectual disability, disorders that may be the cause of pathological body posture: genetic syndromes, hormonal disorders, neuromuscular diseases, congenital defects of the locomotor system, age below 7 and above 8 , no written consent for testing. Children took part in curricular physical education classes three times a week. The vast majority did not engage in competitive sports at sports clubs. The tests were carried out with the consent of the University Bioethics Committee. The spine was examined via the optoelectronic method - Diers formetric III 4D (DIERS International GmbH Dillenbergweg 4/65388 Schlangenbad, Germany). Three-dimensional analysis of the spine is a combination of the latest optical imaging technique and digital data processing using raster stereography $[16,17]$. This is a fast and non-contact $4 \mathrm{D}$ photogrammetric measurement $[18,19]$. The measurement results are very precise, and thanks to the quick transfer of the image to a computer, data analysis takes place immediately after the test [20]. The study was conducted with the DiCAM 'Average' programme. Following the Diers formetric III 4D manual, for the assessment of scoliotic posture and scoliosis, the following classification was made:

- scoliotic posture - pelvic tilt 1-4 mm, lateral deviation (rms) $1-4 \mathrm{~mm}$, rotation (rms) $1-4^{\circ}$,

- scoliosis - pelvic tilt equal to or greater than $5 \mathrm{~mm}$, lateral deviation (rms) equal to or greater than $5 \mathrm{~mm}$, rotation (rms) equal to or greater than $5^{\circ}$.

All the parameters registered by the Diers formetric III $4 \mathrm{D}$ were collected in a totally non-invasive way, and the device was safe for the whole group. On their basis, the Diers formetric III 4D standardisation of results was also performed. X-ray imaging provides direct and illustrated information about the form and deviations from the norm, but only in two-dimensional projection. In addition, the disadvantage of X-ray testing is the detrimental effect of radiation, which makes it impossible to take check-up images at shorter intervals. The Diers formetric III 4D method is a non-contact and, above all, non-radiating measurement method [21, 22].

Surface electromyography (SEMG) of the erector spinae was performed using a 12-channel NoraxonTeleMyo DTS apparatus (Noraxon U.S.A. Inc. 15770
North Greenway-Hayden Loop, Suite 100, Scottsdale, Arizona 85260). The device had an EC certificate (Certificate Production Quality Assurance Directive 93/42/EEC Medical Devices Annex V) [23]. In this study, $30 \mathrm{~mm}$ diameter pre-gel electrodes were used. At the point of application, the skin was cleaned with an abrasive fluid to obtain resistance between the skin and an electrode below $2 \mathrm{k} \Omega$. The electrodes were located parallel to the direction of the tested muscle fibres. The distance between them was $20 \mathrm{~mm}$. The SEMG amplitude of the erector spinae was examined in the thoracic and lumbar segments on both sides of the spine. A raw signal appeared on the computer screen preceding the SEMG target recording. The raw signal was recorded and analysed. The program that modified the signal and cleared the raw record from extreme, maximal and minimal deflections was selected. Then the raw signal processing option was chosen to calculate the average SEMG amplitude. The processed mean SEMG amplitude of the erector spinae expressed in millivolts $(\mathrm{mV})$ was further recorded [24]. The test results included a voltage scale at a time interval of $100 \mathrm{~ms}$. The study used the continuous track recording mode. The SEMG amplitude was recorded for the erector spinae on both sides, in the thoracic and lumbar regions at the apex of the curvature:

- in a habitual standing position;

- in resting position: prone position (lower limbs extended in the knee joints, upper limbs placed along the trunk);

- under isometric contraction:

- prone position (lower limbs extended in the knee joints, upper limbs place along the trunk, stabilised pelvis); the subject lifted the trunk within the range of mobility of the lumbar spine (approximately $30^{\circ}$ ), after which s/he maintained this position for $10 \mathrm{~s}$,

- prone position, with the upper trunk stabilised (shoulders and chest, limbs arranged as before), the subject lifted both lower limbs within the mobility of the hip joints (approximately $15^{\circ}$ ) for $10 \mathrm{~s}$.

The SEMG amplitude of the erector spinae was used to assess the degree of activity and muscle tone [25]. The SEMG measurement was in accordance with SENIAM recommendations (Surface ElectroMyoGraphy for the Non-Invasive Assessment of Muscles), a European research programme containing a number of guidelines regarding the choice of electrode type, their location, muscle anatomy and function, muscle group tests and signal processing as well as hardware conditions. Both the examination of the spine and the SEMG amplitude of the erector spinae were painless and non-invasive.

\section{Statistical analysis}

In order to determine the normality of variable distributions, the Kolmogorov-Smirnov test was per- 
formed. To assess the most important and statistically significant predictors for dependent variables - the location, direction and number of spinal curvatures - and the independent variable, i.e. the SEMG amplitude of the erector, the multinomial, stepwise and progressive regression models were used:

$\mathrm{Y}=\mathrm{a}+\mathrm{b}_{1} \mathrm{X}_{1}+\mathrm{b}_{2} \mathrm{X}_{2}+\ldots+\mathrm{b}_{\mathrm{n}} \mathrm{X}_{\mathrm{n}}$

The incoming data consisted of the following 16 independent variables: standing position, thoracic segment, left side; standing position, thoracic segment, right side; standing position lumbar segment, left side; standing position, lumbar segment, right side; prone position, thoracic segment, left side; prone position, thoracic segment, right side; prone position, lumbar segment, left side; prone position, lumbar segment, right side; prone, position, trunk up, thoracic segment, left side; prone, position, trunk up, thoracic segment, right side; prone position, trunk up, lumbar segment, left side; prone position, trunk up, lumbar segment, right side; prone position, lower limbs up, thoracic segment, left side; prone position, lower limbs up, thoracic segment, right side; prone position, lower limbs up, lumbar segment, left side; prone position, lower limbs up, lumbar segment, right side. The verifying parameter used to assess the created models was the determination coefficient (adjusted $R^{2}$ ), as well as test statistics and the level of statistical significance, which clearly made it possible to choose models with the assumed level of statistical significance of $p<0.05$.

\section{Results}

There were 141 (56.17\%) children with scoliotic posture, $103(41 \%)$ with scoliosis and $7(3.0 \%)$ with normal posture. Within the group of subjects with scoliosis, the most common was curvature in the thoracic segment. In girls, this was $62 \%$, and in boys $56 \%$. In the group of children with scoliotic posture, thoracic location of curvature was also the most common in both girls (49\%) and boys (45\%). Left-sided curvature was slightly more common in girls, both in the scoliosis (41\%) and in the scoliotic posture group. On the other hand, right-sided curvature prevailed in boys. The most common were single curvatures among girls in the scoliosis group, which totalled $77 \%$, and in the group with scoliotic posture, this reached $63 \%$, while among boys in the scoliosis group, this value was 56\% and $52 \%$ in the group with scoliotic posture (Table 1 ). The values of location and dispersion measures for the amplitude of the SEMG of the erector spinae had different distributions in both girls and boys and in all groups. Among the girls, the greatest absolute differentiation occurred for the variable prone position, lumbar segment, right side in the scoliosis group $(\mathrm{S}=47.58)$, scoliotic posture $(\mathrm{S}=47.22)$ and the group with correct posture $(S=56.48)$. Among boys, the greatest absolute differentiation also occurred for the variable prone position, lumbar segment, right side in both the scoliosis group $(S=51.33)$ and the group with scoliotic posture $(S=47.00)$. However, in the group with normal posture, among boys, the greatest absolute differentiation was observed for the variable trunk up, thoracic segment, right side $(S=48.29)$. In girls, the highest generalised amplitude was in the case of scoliosis ( $x=47.175 \mathrm{mV})$, and similarly, in boys with scoliosis $(x=48.726 \mathrm{mV})$.

\section{Spinal curvature location and SEMG} amplitude of the erector spinae

The regression model for the group with normal posture did not reach the assumed level of statistical significance; therefore, it was not shown nor was it recognised as correct in modelling the relationship between the EMG amplitude of the erector and the location of scoliosis. There was a significant correlation between the location of the curvature and the amplitude of the erector spinae in both the scoliosis and scoliotic posture groups. In scoliosis, statistically significant model predictors were the frequency tested in prone position, lower limbs up, lumbar segment, right side ( $p=0.001)$; prone position, thoracic segment, left side $(p=0.02)$; standing position lumbar segment, left side ( $p=0.01)$; standing position, thoracic segment, right side ( $p=0.01$ ); prone position, lower limbs up, lumbar segment, left side $(p=0.02)$. The variance explained by the independent variables adopted in the model accounted for $42 \%$ of the total variability $\left(R^{2}=0.42\right)$, which indicates an average fit to the data, but the assumed level of statistical significance $(p=0.001)$ was met, and the appropriate value of the statistical test $F=4.79$ was also reached. In the group of with scoliotic posture, statistically significant model predictors were the amplitude tested in prone position, trunk up, lumbar segment, left side ( $p=0.01)$; and standing position, thoracic segment, right side $(p=0.02)$. The model explained only $31 \%$ of the variability $\left(R^{2}=0.31\right)$, i.e. less than half, but the assumed level of statistical significance ( $p=0.04$ ) was also met, and the appropriate value of the statistical test $F=2.69$ was obtained (Table 2).

\section{Spinal curvature direction and SEMG amplitude of the erector spinae}

The regression model for the group with normal posture did not reach the assumed level of statistical significance; therefore, it was not shown, nor was it recognised as correct in modelling the relationship between EMG amplitude and the direction of scoliosis. There was a significant correlation between the direction of the curvature and the amplitude of the erector spinae in both the scoliosis group and the group with scoliotic postures. In scoliosis, statistically significant model predictors were the frequency tested in prone 
Table 1. Location, direction and number of spinal curvatures

\begin{tabular}{|c|c|c|c|c|c|c|}
\hline \multirow[t]{2}{*}{ Location of curvature } & \multicolumn{2}{|c|}{ Scoliosis } & \multicolumn{2}{|c|}{ Scoliotic posture } & \multicolumn{2}{|c|}{ Norm } \\
\hline & $N$ & $\%$ & $N$ & $\%$ & $N$ & $\%$ \\
\hline \multicolumn{7}{|c|}{ Location of curvature in girls: } \\
\hline Thoracic & 24 & 62 & 34 & 49 & 0 & 0 \\
\hline Thoracolumbar & 8 & 21 & 24 & 34 & 3 & 75 \\
\hline Lumbar & 7 & 18 & 12 & 17 & 1 & 25 \\
\hline \multicolumn{7}{|c|}{ Location of curvature in boys: } \\
\hline Thoracic & 36 & 56 & 32 & 45 & 0 & 0 \\
\hline Thoracolumbar & 19 & 30 & 26 & 37 & 1 & 33 \\
\hline Lumbar & 9 & 14 & 13 & 18 & 2 & 67 \\
\hline \multicolumn{7}{|c|}{ Direction of curvature in girls: } \\
\hline Left-sided & 16 & 41 & 23 & 33 & 0 & 0 \\
\hline Right-sided & 14 & 36 & 21 & 30 & 1 & 25 \\
\hline Right-/left-sided & 3 & 8 & 6 & 9 & 0 & 0 \\
\hline Left-/right-sided & 6 & 15 & 20 & 29 & 3 & 75 \\
\hline \multicolumn{7}{|c|}{ Direction of curvature in boys: } \\
\hline Left-sided & 18 & 28 & 18 & 25 & 0 & 0 \\
\hline Right-sided & 18 & 28 & 20 & 28 & 2 & 67 \\
\hline Right-/left-sided & 5 & 8 & 15 & 21 & 1 & 33 \\
\hline Left-/right-sided & 23 & 36 & 18 & 25 & 0 & 0 \\
\hline \multicolumn{7}{|c|}{ Number of curvatures in girls: } \\
\hline One & 30 & 77 & 44 & 63 & 1 & 25 \\
\hline Two & 9 & 23 & 26 & 37 & 3 & 75 \\
\hline \multicolumn{7}{|c|}{ Number of curvatures in boys: } \\
\hline One & 36 & 56 & 37 & 52 & 2 & 67 \\
\hline Two & 28 & 44 & 34 & 48 & 1 & 33 \\
\hline
\end{tabular}

position, trunk up, thoracic segment, left side $(p=0.03)$ and prone position, lower limbs up, thoracic segment, right side $(p=0.03)$. The variance explained by the independent variables adopted in the model accounts for $29 \%$ of the total variability $\left(R^{2}=0.29\right)$, which indicates a low fit to the data, but the assumed level of statistical significance ( $p=0.02$ ) was met, and the appropriate value of the statistical test $F=3.2$ was obtained. In the group with scoliotic posture, statistically significant model predictors were the amplitude tested in prone position, position, trunk up, thoracic segment, right side $(p=0.04)$; standing position, thoracic segment, right side ( $p=0.001)$; prone position, lumbar segment, right side $(p=0.01)$; and standing position, thoracic segment, left side $(p=0.02)$. The model explained only $39 \%$ of the variability $\left(R^{2}=0.39\right)$, i.e. less than half, but the assumed level of statistical significance $(p=0.02)$ was also met, and the appropriate value of the statistical test $F=2.47$ was obtained (Table 3 ).

\section{Number of spinal curvatures and SEMG} amplitude of the erector spinae

The regression model for the scoliosis group and the normal group did not achieve the assumed statistical significance; therefore, it was not shown, nor was it considered correct in modelling the relationship between the SEMG amplitude and the number of curvatures. There was also a significant correlation between the number of spinal curvatures and the amplitude of the erector spinae in the scoliosis group. In scoliosis, statistically significant model predictors were the frequency tested in prone position, trunk up, lumbar segment, left side $(p=0.01)$; and prone position, thoracic segment, left side $(p=0.02)$. The model explained $41 \%$ of the variability $\left(R^{2}=0.41\right)$, i.e. less than half, but the assumed level of statistical significance ( $p=0.001)$ was also met, and the appropriate value of the statistical test $F=5.1$ (Table 4) was obtained. 
Table 2. Progressive stepwise regression model for the location of curvature

\begin{tabular}{|c|c|c|c|c|c|c|}
\hline Variable & $\beta$ & $\begin{array}{l}\text { Std. error } \\
\quad \mathrm{Z} \beta\end{array}$ & b & $\begin{array}{l}\text { Std. error } \\
\quad \mathrm{Z} \mathrm{b}\end{array}$ & $t(97)$ & $P$-value \\
\hline \multicolumn{7}{|l|}{ Scoliosis group: } \\
\hline Constant/absolute term & & & 2.08 & 0.25 & 8.48 & 0.001 \\
\hline $\begin{array}{l}\text { Prone position, lower limbs up, lumbar segment, } \\
\text { right side }\end{array}$ & 0.39 & 0.10 & 0.01 & 0.00 & 3.93 & 0.001 \\
\hline Prone position, thoracic segment, left side & -0.20 & 0.08 & -0.01 & 0.00 & -2.40 & 0.02 \\
\hline Standing position lumbar segment, left side & 0.24 & 0.09 & 0.01 & 0.01 & 2.62 & 0.01 \\
\hline Standing position, thoracic segment, right side & -0.36 & 0.13 & -0.01 & 0.00 & -2.73 & 0.01 \\
\hline $\begin{array}{l}\text { Prone position, lower limbs up, lumbar segment, } \\
\text { left side }\end{array}$ & -0.35 & 0.14 & -0.01 & 0.00 & -2.42 & 0.02 \\
\hline \multicolumn{7}{|c|}{$R=0.42 ; R^{2}=0.18 ;$ Correction $R^{2}=0.14 ; F(6.134)=4.79 ; p=0.001$} \\
\hline \multicolumn{7}{|l|}{ Scoliotic posture group: } \\
\hline Constant/absolute term & & & 2.81 & 0.29 & 9.82 & 0.001 \\
\hline Prone position, trunk up, lumbar segment, left side & 0.35 & 0.12 & 0.02 & 0.01 & 2.83 & 0.01 \\
\hline Standing position, thoracic segment, right side & -0.37 & 0.16 & -0.01 & 0.00 & -2.36 & 0.02 \\
\hline
\end{tabular}

Table 3. Progressive stepwise regression model for the direction of curvature

\begin{tabular}{|c|c|c|c|c|c|c|}
\hline Variable & $\beta$ & $\begin{array}{l}\text { Std. error } \\
\quad Z \beta\end{array}$ & b & $\begin{array}{l}\text { Std. error } \\
\quad \mathrm{Z} \mathrm{b}\end{array}$ & $t(95)$ & $P$-value \\
\hline \multicolumn{7}{|l|}{ Scoliosis group: } \\
\hline Constant/absolute term & & & 3.06 & 0.34 & 8.91 & 0.001 \\
\hline Prone, position, trunk up, thoracic segment, left side & -0.24 & 0.11 & -0.01 & 0.00 & -2.19 & 0.03 \\
\hline $\begin{array}{l}\text { Prone position, lower limbs up, thoracic segment, } \\
\text { right side }\end{array}$ & -0.21 & 0.09 & -0.01 & 0.00 & -2.22 & 0.03 \\
\hline \multicolumn{7}{|c|}{$R=0.29 ; R^{2}=0.09 ;$ Correction $R^{2}=0.06 ; F(4.136)=3.2 ; p=0.02$} \\
\hline \multicolumn{7}{|l|}{ Scoliotic posture group: } \\
\hline Constant/absolute term & & & 1.93 & 0.45 & 4.30 & 0.001 \\
\hline Prone, position, trunk up, thoracic segment, right side & -0.33 & 0.16 & -0.01 & 0.01 & -2.11 & 0.04 \\
\hline Standing position, thoracic segment, right side & 1.26 & 0.40 & 0.05 & 0.02 & 3.17 & 0.001 \\
\hline Prone position, lumbar segment, right side & -0.98 & 0.36 & -0.02 & 0.01 & -2.71 & 0.01 \\
\hline Standing position, thoracic segment, left side & -0.30 & 0.13 & -0.03 & 0.01 & -2.37 & 0.02 \\
\hline \multicolumn{7}{|c|}{$R=0.39 ; R^{2}=0.15 ;$ Correction $R^{2}=0.09 ; F(7.95)=2.47 ; p=0.02$} \\
\hline
\end{tabular}

Table 4. Progressive stepwise regression model for the number of curvatures

\begin{tabular}{|c|c|c|c|c|c|c|}
\hline Variable & $\beta$ & $\begin{array}{c}\text { Std. error } \\
\text { Z } \beta\end{array}$ & b & $\begin{array}{c}\text { Std. error } \\
\text { Z b }\end{array}$ & $t(132)$ & $P$-value \\
\hline \multicolumn{7}{|l|}{ Scoliosis group: } \\
\hline Constant/absolute term & & & 0.46 & 0.44 & 1.05 & 0.30 \\
\hline Prone position, trunk up, lumbar segment, left side & 0.28 & 0.11 & 0.01 & 0.00 & 2.62 & 0.01 \\
\hline Prone position, thoracic segment, left side & -0.37 & 0.16 & -0.01 & 0.00 & -2.33 & 0.02 \\
\hline \multicolumn{7}{|c|}{$R=0.41 ; R^{2}=0.17 ;$ Correction $R^{2}=0.14 ; F(4.98)=5.1 ; p=0.001$} \\
\hline
\end{tabular}




\section{Discussion}

In our research, we have confirmed that curvatures located in the thoracic segment are most common in school-children. In the group of girls, left-sided thoracic scoliosis slightly prevailed, of which there were 16 cases (41\%), and only 2 less totalling $14(36 \%)$ regarded right-sided curvatures (Table 1). We explain this by the fact that in the whole study group, lowgrade scoliosis not exceeding $30^{\circ}$ prevailed. There is information in the subject literature stating that in low-grade scoliosis, left-sided $(63.0 \%)$ is more common than right-side $\mathrm{d}$ scoliosis $(37.0 \%)$. It is only in curvatures above $30^{\circ}$ that the right-sided, more often double-curvatures, compensation-related, right-sided thoracic and lumbar-left curvatures predominate. These curvatures have the worst prognosis and sometimes require surgery. Also, in the case of curvatures appearing before the age of 3 , the primary curvature is located in part in the thoracic segment and is usually left-sided. Double curvatures are less common [25]. In both girls and boys, the largest generalised amplitude was in scoliosis $(x=47.175 \mathrm{mV})$, and similarly in boys with scoliosis ( $x=48.726 \mathrm{mV}$ ) (Tables 2, 3).

The presented research showed a significant relationship between the location, direction and number of spinal curvatures and the SEMG amplitude of the erector spinae. Among the concepts regarding the formation and development of idiopathic scoliosis, the theory of muscular tension disorders is particularly important [26]. In this theory, muscle disorders are treated as secondary and resulting from unaltered changes occurring in the central nervous system. On the other hand, muscular disorders are primary in relation to bone changes [27]. Together, this creates a set of changes that form a clinical and anatomopathological image of idiopathic scoliosis. In many studies, researchers point to the key importance of the nervous system in the pathogenesis of scoliosis. Via impulsation from the brain or cerebellum through vegetative pathways, segmental, tonic muscle contraction occurs in the segments affected by reflex [10]. The result of chronic, isotonic contraction of the deep back muscles is the rotation of the vertebrae, as well as a gradual contracture of the rotator muscles. As a result, contractures and degenerations of the ligamentous joints of the spine occur, correlating with the functional shortening of the long back muscles on the concave side of the curvature [28].

In the early 1960s, the first studies on deep muscles using electromyography were carried out. Żuk [29], in his EMG measurements, found a higher amplitude on the concave side of the spine in most cases. Research performed by Tokarowski [30] indicated muscular dystrophy manifesting itself primarily on the concave side of the curvature. Tylman [28] noted that lateral curvature of the spine is directed with convexity in the direction with less muscular tension. Chwała et al. [31], in patients performing asymmetric exercises of the erector spinae muscles, noted different muscle tension on the electromyographic recording both on the convex and concave sides of the spine. In the 1980s, Cassidy et al. [32] analysed the role of erector spinae muscles in the pathogenesis of idiopathic scoliosis during gait using EMG. Out of the 10 patients examined, 6 had higher muscle tone amplitude on the convex side of the curvature. Farahpour et al. [33] performed EMG tests in patients with scoliosis, in which they found a link between curvature of the spine and uneven tension of the erector spinae muscles. Stetkarova et al. [34] noted higher tension amplitude in the paravertebral muscles and changes in muscle fibres on the convex side of the spine. Guo et al. [35] observed reduced EMG activity on the concave side and increased dynamics on the convex side of the paravertebral muscles in patients with scoliosis during rest. Elattar et al. [36], on the EMG record, found a correlation between an increase in muscle tone and a progressive increase in the angle of curvature on the convex side measured via the Cobb method. Thouin and Mathieu [37] electromyographically examined patients considering the division into those with a scoliotic attitude and those with diagnosed scoliosis. He recorded higher values of EMG signals in patients with scoliotic posture on the concave side, while in patients with scoliosis higher values were recorded on the convex side. Arendt-Nielsen et al. [38] noted that the tension signal during electromyographic examination increases during muscle contraction. Trontelj et al. [39] noted uneven tension of the paravertebral muscles in people with scoliosis at the apex of the curvatures. In other measurements, based on EMG analysis, Kwok et al. [40] stated that not all patients with scoliosis had asymmetrical muscle tension. In some cases, it was evenly distributed. Usig EMG, Richardson et al. [41] determined that in healthy subjects, the erector spinae muscles during elevation of the trunk work using $76-79 \%$ of their potential. In the case of scoliosis between $20^{\circ}$ and $50^{\circ}$, Tsai et al. [42] noted significant asymmetry in the EMG record of the erector spinae muscle in the thoracic spine segment. EMG testing allows precise determination of motor functions in patients with locomotor dysfunctions, and enables recording of natural muscle activation signals. Thanks to electromyographic examination, patients with scoliosis experienced delayed back muscle reaction on the convex side of the lumbar segment relative to the concave side. Similar results were obtained by Toosizadeh et al. [43] in the case of muscles located at the height of the thoracic segment. From the beginning of research on erector spinae electromyography, it has been noted that there is a relationship between erector spinae muscle activity, tension and fatigue, and features of scoliosis. In most studies, an increase in paravertebral muscle amplitude on the convex side of curvature has been found. 
The results of our research confirms that disorders of muscle tension play an important role in progression of scoliosis [26]. Probably, abnormalities in tension of the back muscles are secondary, and are the result of yet unknown changes in the CNS [10]. On the other hand, muscle dysfunctions are primary to the bone changes. In many studies on the pathogenesis of scoliosis, scientists point to the key role of the nervous system [10]. Our studies are also important for the treatment of scoliosis. They confirm the opinion that the mechanical perception of the role of back muscles in the treatment of scoliosis without relating their function with CNS causes unjustified focusing on the formation of a so-called muscular "corset", to be more precise, on exercises that develop the strength and endurance of postural muscles. This element of the mentioned procedure is surely important, but the approach to the functioning of these muscles must be completely different. There is abundant evidence that despite the significant strength and endurance of postural muscles, incorrect posture is often adopted, even scoliosis develops, and corrective treatment does not bring the expected results. Kinesiotherapy of scoliosis is not associated with strengthening of individual groups of postural muscles, but with the integration of their functions in static, positioning and equilibrium reactions, in connection with the CNS function. In the treatment of scoliosis, the EMG biofeedback method is useful. The novelty of our research is also that it was carried out on a group of small, 7-8 year-old children with slight scoliosis and scoliotic postures.

We hope our research will help ensure that in the future there will be a model record for EMG amplitude of the postural muscles, characteristic for a child with scoliosis. Then, based on electromyographic examination, it will be possible to capture the initial symptoms of scoliosis and start preventive rehabilitation before irreversible bone changes occur. Idiopathic scoliosis is merely a symptom, an external expression of the CNS dysfunction not fully recognised, also visible on the EMG record of postural muscles. Imaging of the CNS (PET, RM, DTI) in combination with EMG and genetic tests will probably explain the aetiology of idiopathic scoliosis in the future [44].

\section{Conclusions}

The greatest generalised SEMG amplitude of the erector spinae occurred in scoliosis among both girls and boys. A significant relationship between the location, direction and number of spinal curvatures and SEMG amplitude of the erector spinae has been demonstrated. The increase in erector spinae activity correlates with the progression of scoliosis.

\section{Acknowledgments}

The data used to support the findings of this study are available from the corresponding author upon request.
The project is supported within the framework of the programme funded by the Minister of Science and Higher Education under the name "Regional Initiative of Excellence" in 2019-2022, project number: 024/RID/2018/19.

\section{Conflict of interest}

The authors declare no conflict of interest.

\section{References}

1. Dubousset J, Chopin D, Seringe R. Have we made true progress in surgical indications and determining the limitations of spinal fusion in patients with idiopathic scoliosis? Orthop Traumatol Surg Res 2018; 104: 555-556.

2. Fadzan M, Bettany-Saltikov J. Etiological theories of adolescent idiopathic scoliosis: past and present. Open Orthop J 2017; 29: 1466-1489.

3. Kokabu T, Kawakami N, Uno K, Kotani T, Suzuki T, Abe Y, Maeda K, Inage F, Ito YM, Iwasaki N, Sudo H. Three-dimensional depth sensor imaging to identify adolescent idiopathic scoliosis: a prospective multicenter cohort study. Sci Rep 2019; 9: 9678.

4. Gadya AD, Borde MD, Kumar N, Patel PM, Nagad PB, Bhojraj SY. Analysis of the functional and radiological outcomes of lumbar decompression without fusion in patients with degenerative lumbar scoliosis. Asian Spine J 2020; 14: 9-16.

5. Archer IA, Dickson RA. Stature and idiopathic scoliosis a prospective study. J Bone Joint Surg 1985; 67: 185-188.

6. Schreiber S, Parent EC, Hill DL, Hedden DM, Moreau MJ, Southon SC. Patients with adolescent idiopathic scoliosis perceive positive improvements regardless of change in the Cobb angle - results from a randomized controlled trial comparing a 6-month Schroth intervention added to standard care and standard care alone. SOSORT 2018 Award winner. BMC Musculoskelet Disord 2019; 20: 319.

7. Kennedy J, Hoffmann T, Unasa H, Frampton C, Howard A, Kiely PJ, Crawford H. Thoracic proportions in children without scoliosis. J Child Orthop 2019; 13: 304-309.

8. Zapata KA, Sucato DJ, Jo CH. physical therapy scoliosisspecific exercises may reduce curve progression in mild adolescent idiopathic scoliosis curves. Pediatr Phys Ther 2019; 31: 280-285.

9. Feipel V, Aubin CE, Ciolofan OC, Beauséjour M, Labelle $\mathrm{H}$, Mathieu PA. Electromyogram and kinematic analysis of lateral bending in idiopathic scoliosis patients. Med Biol Eng Comput 2002; 40: 497-505.

10. Burwell RG, Dangerfield PH, Freeman BJC. Etiologic theories of idiopathic scoliosis. Somatic nervous system and the NOTOM. Escalator concept as one component in the pathogenesis of adolescent idiopathic scoliosis. Stud Health Technol Inform 2008; 140: 208-217.

11. Lo YL, Teo A, Tan YE, Fook-Chong S, Guo CM, Yue WM. Motor and somatosensory abnormalities are significant etiological factors for adolescent idiopathic scoliosis. J Neurol Sci 2015; 359: 117-123.

12. Doménech J, Tormos JM, Barrios C, Pascual-Leone A. Motor cortical hyperexcitability in idiopathic scoliosis: could focal dystonia be a subclinical etiological factor? Eur Spine J 2010; 19: 223-230.

13. Doménech J, Garcia-Marti G, Marti-Bonmati L, Barrios C, Tormos JM, Pascual-Leone A. Abnormal activation of the 
motor cortical network in idiopathic scoliosis demonstrated by functional MRI. Eur Spine J 2011; 20: 1069-1078.

14. Henssge J. Electromyographic contribution to the problem of scoliosis. Z Orthop Ihre Grenzgeb 1964; 99: 167-195.

15. Perret C, Robert J. Electromyographic responses of paraspinal muscles to postural disturbance with special reference to scoliotic children. J Manipulative Physiol Ther 2004; 27: 375-380.

16. Hierholzer E, Drerup B. Influence of length discrepancy on rasterstereographic back shape parameters. Orthopade 2001; 30: 242-250.

17. Humbert L, Steffen JS, Vialle R, Dubousset J, Vital JM, Skalli W. 3D analysis of congenital scoliosis due to hemivertebra using biplanar radiography. Eur Spine J 2013; 22: 379-386.

18. Drerup B, Hierholzer E, Frobin W. Oberflächenvermessung bei Wirbelsäulendeformitäten. Vorabdruck anlässlich der 69. Tagung der deutschen Gesellschaft für Orthopädie und Traumatologie. Mainz, 1982: 13-18.

19. Schulte TL, Hierholzer E, Boerke A. Raster stereography versus radiography in the long-term follow-up of idiopathic scoliosis. J Spinal Disord Tech 2008; 21: 23-28.

20. Mohokum M. Reproducibility of rasterstereography for kyphotic and lordotic angles and for trunk length and trunk inclination: a reliability study (abstract). Eur Spine J 2009; 18: 1713-1826.

21. Harzmann HCH. Stellenwert der Videorasterstereografie als schulärztliche Screening methode von skoliotischen. Fehlhaltungen und strukturellen Skoliosen. Dissertation. München. Ludwig - Maximilians - Universität. Medizinischen Fakultät 2000.

22. Wilczyński J, Karolak P, Habik-Tatarowska N, Janecka S, Kabała M. The relationship between the angle of curvature of the spine and SEMG amplitude of the erector spinae in young school-children. Appl Sci 2019; 9: 3115.

23. Zetterberg C, Bjüdrk R, Örtengren R, Andersson GBJ Electromyography of the paravertebral muscles in idiopathic scoliosis. Acta Orthop Scand 1984; 55: 304-309.

24. Valentino B, Maccauro L, Mango G, Melito F, Fabozzo A. Electromyography for the investigation and early diagnosis of scoliosis. AnatClin 1985; 7: 55-59.

25. Ko JY, Lee M, Jang JH, Jang DH, Ryu JS. A novel de novo mutation in MYH7 gene in a patient with early onset muscular weakness and severe kyphoscoliosis: a case report. Medicine 2019; 98: e16389.

26. Boldrey E, Adams JE, Brown HA. Scoliosis as a manifestation of disease of the cervicothoracic portion of the spinal cord. Arch Neurol Psychiatry 1949; 61: 528-544.

27. Stilwell DL. Structural deformities of vertebrae. Bone adaptation and modeling in experimental scoliosis and kyphosis. J Bone Joint Surg Am 1962; 44: 611-634.

28. Tylman D. Pathomechanics of lateral spinal curvatures. Severus, Warsaw 1995.

29. Żuk T. Etiology and pathogenesis of idiopathic scoliosis from the viewpoint of electromyographic studies. Beitr Orthop Traumatol 1965; 12: 138-141.

30. Tokarowski A. Miomechanika idiopatycznych bocznych skrzywień kręgosłupa w świetle badań elektromiograficznych. Chirurgia Narządów Ruchu i Ortopedia Polska 1965; 30: 385-390.

31. Chwała W, Koziana A, Kasperczyk T, Walaszek R, Płaszewski M. Electromyographic assessment of functional symmetry of paraspinal muscles during static exercises in adolescents with idiopathic scoliosis. Biomed Res Int 2014; 2014: 573276.

32. Cassidy JD, Brandell BR, Nykoliation J, Wedge J. The role of paraspinal muscles in the pathogenesis of idiopathic scoliosis: a preliminary EMG studies. J Canad Chirop Assoc 1987; 31: 179-184.

33. Farahpour N, Younesian H, Bahrpeyma F. Electromyographic activity of erector spinae and external oblique muscles during trunk lateral bending and axial rotation in patients with adolescent idiopathic scoliosis and healthy subjects. Clin Biomechan 2015; 30: 411-417.

34. Stetkarova I, Zamecnik J, Bocek V, Vasko P, Brabec K, Krbec M. Electrophysiological and histological changes of paraspinal muscles in adolescent idiopathic scoliosis. Eur Spine J 2016; 25: 3146-3153.

35. Guo LY, Wang YL, Huang YH, Yang CH, Hou YY, Harn HI, You YL. Comparison of the electromyographic activation level and unilateral selectivity of erector spinae during different selected movements. Int J Rehabil Res 2012; 35: 345-351.

36. Elattar EA, Saber NZ, Farrag DA. Predictive factors for progression of adolescent idiopathic scoliosis: a 1-year study. Egypt Rheumatol Rehabil 2015; 3: 111-119.

37. Thouin JF, Mathieu PA. International Research Society of Spinal Deformities. Vancouver 2004.

38. Arendt-Nielsen L, Mills KR. Muscle fibre conduction velocity, mean power frequency, mean EMG voltage and force during submaximal fatiguing contractions of human quadriceps. Eur J Appl Physiol 1988; 58: 20-25.

39. Trontelj JV, Fernandez JM. Single fiber EMG in juvenile idiopathic scoliosis. Muscle Nerve 1988; 11: 297-300.

40. Kwok G, Yip J, Cheung MC, Yick KL. Evaluation of myoelectric activity of paraspinal muscles in adolescents with idiopathic scoliosis during habitual standing and sitting. Biomed Res Int 2015; 2: 95

41. Richardson C, Hodges P, Hides J. Therapeutic exercise for lumbopelvic stabilization: a motor control approach for the treatment and prevention of low back pain. $2^{\text {nd }}$ ed. Churchill Livingstone, London 2004.

42. Tsai YT, Leong CP, Huang YC, Kuo SH, Wang HC, Yeh HC, Lau YC. The electromyographic responses of paraspinal muscles during isokinetic exercise in adolescents with idiopathic scoliosis with a Cobb's angle less than fifty degrees. Chang Gung Med J 2010; 33: 540-550.

43. Toosizadeh N, Chuan Yen T, Howe C, Dohm M, Mohler J, Najafi B. Gait behaviors as an objective surgical outcome in low back disorders: a systematic review. Clin Biomech 2015; 30: 528-536.

44. Sadler B, Haller G, Antunes L, Bledsoe X, Morcuende J, Giampietro P, Raggio C, Miller N, Kidane Y. Distal chromosome 16p11.2 duplications containing SH2B1 in patients with scoliosis. J Med Genet 2019; 56: 427-433.

\section{Address for correspondence:}

\section{Prof. Jacek Wilczyński}

Institute of Health Sciences

Collegium Medicum

Jan Kochanowski University

Kielce, Poland

Phone: +48 603703926

E-mail: jwilczynski@onet.pl 